\title{
The Presence of Macromolecular Prolactin in Serum of Pregnant Women and Patients with Pituitary Adenoma
}

\author{
Shumpei OHNAMI ${ }^{1}$ and Sumiya ETO $^{2}$ \\ ${ }^{1}$ Unit of Radiology, ${ }^{2}$ First Department of Internal Medicine, School of Medicine, \\ University of Occupational and Environmental Health, Japan. Kitakyushu 807, Japan
}

\begin{abstract}
The heterogeneity of immunoreactive Prolactin (IR-PRL) in serum of pregnant women and patients with pituitary adenoma were studied by Sephadex G-100 gel chromatography. The major IR-PRL peaks in serum of pregnant women were eluted at the position corresponding to that of ${ }^{125}$ I-PRL and the small amount of IR-PRL peaks were eluted near the void volume (peak 1 ) and between the void volume and ${ }^{125}$ I-PRL (peak 2). On the other hand, the proportion of peak 1 and peak 2 to total immunoreactivity was significantly increased in serum of patients with pituitary adenoma compared to those in serum of pregnant women. The rechromatographic studies under conditions of protein denaturation and sulfide cleavage on Sepharose CL-6B column revealed that the peak 1 of the pregnant women and patients with pituitary adenoma were eluted at the position between ${ }^{125} \mathrm{I}$-AFP and ovalbumine and the molecular weight was estimated to be about 54,000. This macromolecular PRL was also bound specifically to Sepharose coupled with anti-PRL, indicating that this macromolecule contained a sequence of PRL in its structure.
\end{abstract}

Key words: prolactin, heterogeneity, macromolecular prolactin, pituitary adenoma.

(Received 28 February 1985)

\section{Introduction}

The presence of several forms of immunoreactive prolactin (IR-PRL) with different molecular weights has been reported in the serum of pregnant women, patients with various pituitary adenoma and normal subjects after TRH administration (Suh et al., 1974; Rogol et al., 1974; Kiefer et al., 1978; Whittaker et al., 1981; Kataoka., 1981; Shoupe et al., 1983), but the physiological significance of such heterogeneous forms of PRL has not been understood.

Recently, Benveniste et al. (1979) has shown that mercaptoethanol almost entirely converted IR-PRL eluted between the void volume and monomeric PRL to monomeric PRL through the reduction of disulfide bonds, however, IR-PRL eluted near the void volume has not yet been elucidated.

In the present study, we have examined the heterogeneity of IR-PRL in serum obtained from pregnant women and patients with pituitary adenoma using Sephadex G100 gel chromatography, Sepharose CL-6B column chromatography, activated CHSepharose $4 \mathrm{~B}$ affinity chromatography and sensitive RIA for PRL. 


\section{Materials and Methods}

\section{Subjects}

Blood samples were obtained from 8 pregnant women and 5 patients with pituitary adenoma (4 patients with PRL secreting pituitary adenoma and 1 patient with GH secreting pituitary adenoma). Blood was allowed to clot at room temperature, centrifuged, and serum samples were stored at $-20^{\circ} \mathrm{C}$ until used.

\section{Radioimmunoassay (RIA)}

IR-PRL levels were determined with a RIA kit supplied by Dinabbot Radioisotope Laboratories, Chiba, Japan. The sensitivity of the assay systems was $0.1 \mathrm{ng} /$ tube. The inter- and intraassay coefficients of variation were $5.5 \%$ and $3.9 \%$, respectively.

\section{Sephadex G-100 column chromatography}

One to $3 \mathrm{ml}$ of serum samples were applied to a $2.5 \times 50 \mathrm{~cm}$ Sephadex G-100 column equilibrated with $0.1 \mathrm{M}$ ammonium acetate buffer and eluted with the same solution at $4^{\circ} \mathrm{C}$. The flow rate was $8 \mathrm{ml} / \mathrm{hr}$ and the fraction volume was $2 \mathrm{ml}$. Each fraction was lyophylized and reconstituted by $0.5 \mathrm{ml}$ of the standard diluent $(0.1 \mathrm{M}$ phosphate buffer, $\mathrm{pH} 7.4$ containing $0.15 \mathrm{M} \mathrm{NaCl}$ and $2 \% \mathrm{BSA}$ ) when assayed. The column was calibrated with blue dextran, ${ }^{125} \mathrm{I}-\mathrm{AFP},{ }^{125} \mathrm{I}-\mathrm{PRL}$ and $\mathrm{Na}^{-125} \mathrm{I}$ for the external

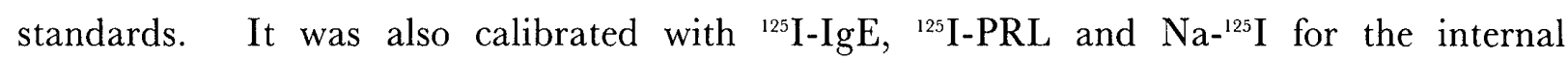
standards. Recovery of PRL standard applied to the column was $75 \%$ or greater.

\section{Sepharose CL-6B column chromatography}

IR-PRL eluted near the void volume (peak 1) obtained from serum of pregnant women and patients with the pituitary adenoma were lyophylized and then incubated in $0.5 \mathrm{ml}$ of eluent buffer for 4 hours before application. This $0.5 \mathrm{ml}$ of solution was applied to a $1 \times 50 \mathrm{~cm}$ Sepharose GL-6B column equilibrated with $0.1 \mathrm{M}$ ammonium acetate buffer, $\mathrm{pH} 4.8$ containing $6 \mathrm{M}$ guanidine- $\mathrm{HCl}$ and $0.02 \mathrm{M}$ dithiothreitol according to the method of Yamaguchi et al. (1981) and eluted with the same solution at room temperature. The flow rate was $4-5 \mathrm{ml} / \mathrm{hr}$ and the fraction volume was $0.5 \mathrm{ml}$. Each fraction was diluted 10 fold in the standard diluent and assayed for PRL. The column was calibrated with blue dextran 2000 (void volume), ${ }^{125}$ I-AFP (mol. wt. 70,000), ovalbumin (mol. wt. 43,000), chymotrypsinogen A (mol. wt. 25,000), ${ }^{125}$ I-PRL (mol. wt. 22,000), ribonuclease A (mol. wt. 13,700) and $\mathrm{Na}^{-125} \mathrm{I}$ for the external standards. ${ }^{125} \mathrm{I}-\mathrm{IgE},{ }^{125} \mathrm{I}-$ PRL and $\mathrm{Na}^{125} \mathrm{I}$ were used also as internal standards. Recovery of ${ }^{125}$ I-PRL applied to the column was $85 \%$ or greater. 


\section{Results}

Gel filtration on Sephadex G-100

Gel filtration patterns of 8 pregnant women are illustrated in Fig. 1. The major IR-PRL peaks were eluted at the position corresponding to that of ${ }^{125} \mathrm{I}$-PRL. The small amount of IR-PRL peaks were eluted near the ${ }^{125} \mathrm{I}-\mathrm{IgE}$ (peak 1), and between the ${ }^{125} \mathrm{I}-\mathrm{IgE}$ and ${ }^{125}$ I-PRL (peak 2). The proportion of IR-PRL to the total IR-PRL was $8-12 \%$ in peak 1 and $4-9 \%$ in peak 2 , respectively.

Gel filtration patterns of 5 patients with pituitary adenoma are illustrated in Fig. 2. The proportion of IR-PRL to the total IR-PRL was $18-40 \%$ in peak 1 and $5-17 \%$ in peak 2, respectively. Although the proportion of peak 1 or peak 2 varied from serum to serum, the total proportion of the two peaks was significantly increased in the serum from patients with pituitary adenoma $(23-57 \%)$ as compared to the pregnant serum $(12-21 \%)$.

Rechromatography of peak 1 and monomeric PRL

Peak 1 and monomeric PRL from a patient with pituitary adenoma (Fig. 2, D) eluted in a given position on Sephadex G-100 was rechromatographed. As illustrated in Fig. 3, both peak 1 and monomeric PRL emerged as a single peak with no shift in their respective elution pattern.

Affinity chromatography with anti-PRL Sepharose

As shown in Fig. 4, the peak 1 and monomeric PRL applied were almost adsorbed in this column and eluted by the addition of $1 \mathrm{M}$ acetic acid.

\section{Gel filtration on Sepharose CL-6B}

Rechromatographic patterns of peak 1 on Sepharose CL-6B column under conditions of denaturation and sulfide bond cleavage are illustrated in Fig. 5. Peak 1 of a pregnant woman and a patient with PRL secreting pituitary adenoma (Fig. 2, D) were eluted at the position between ${ }^{125} \mathrm{I}$-AFP and ovalbumin.

The molecular weight markers were eluted at the expected positions as shown by the straight line in Fig. 6, indicating that the system was appropriate for estimation of molecular weight of unknown samples. The molecular weight of peak 1 was calculated to be about 54,000 .

\section{Discussion}

We have examined about IR-PRL eluted near the void volume (peak 1) obtained by gel stepwise gel filtration of serum from pregnant women and patients with pituitary adenoma. It had been suggested that the peak 1 is an artifact caused by freezing and 

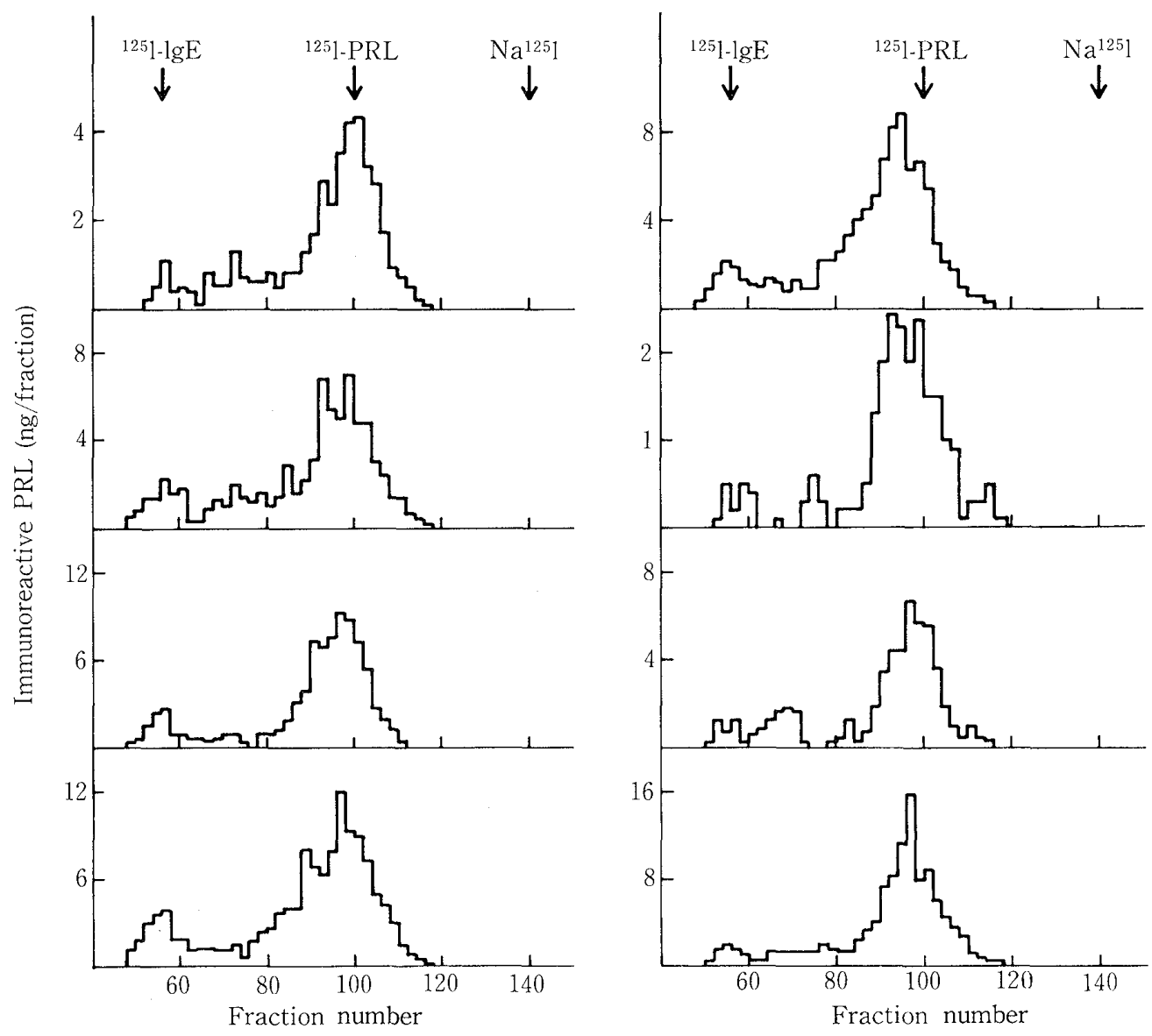

Fig. 1. Gel filtration patterns of IR-PRL in serum obtained from 8 pregnant women on a Sephadex G-100 column $(2.6 \times 50 \mathrm{~cm})$ eluted with $0.1 \mathrm{M}$ ammonium acetate buffer. The substances used for markers are shown at the top.

thawing of samples (Suh \& Franz, 1974; Garnier et al., 1978) and a PRL dimer or monomeric PRL linked with another peptide by one or more disulfide bonds as well as IR-PRL eluted between the void volume and monomeric PRL (Whittaker et al., 1981).

However, in this investigation, rechromatographic studies under conditions of protein denaturation (6 M guanigin $\mathrm{HCl}$ ) and sulfide bond cleavage $(0.02 \mathrm{M}$ dithiothreitol) revealed that the macromolecular PRL still appeared at the high-molecular-weight-position, indicating that such explanations as aggregation of PRL or nonspecific binding to other molecules were unlikely. This macromolecular PRL was almost adsorbed into the affinity column stuffed with activated CH-Sepharose $4 \mathrm{~B}$ coupling with rabbit antiserum to human PRL. These data indicate that the macromolecular PRL contains the sequence of PRL in its structure.

The proportion of peak 1 is significantly increased in the serum of the patients with pituitary adenoma as compared with that of pregnant women. This is not consistent with results reported by Shu \& Frantz (1974), Kiefer \& Malarkey (1974). According to their reports, most of immunoreactivity in the serum of patients with pituitary adenoma and of normal subjects after TRH administration is monomeric PRL. Also, they state 


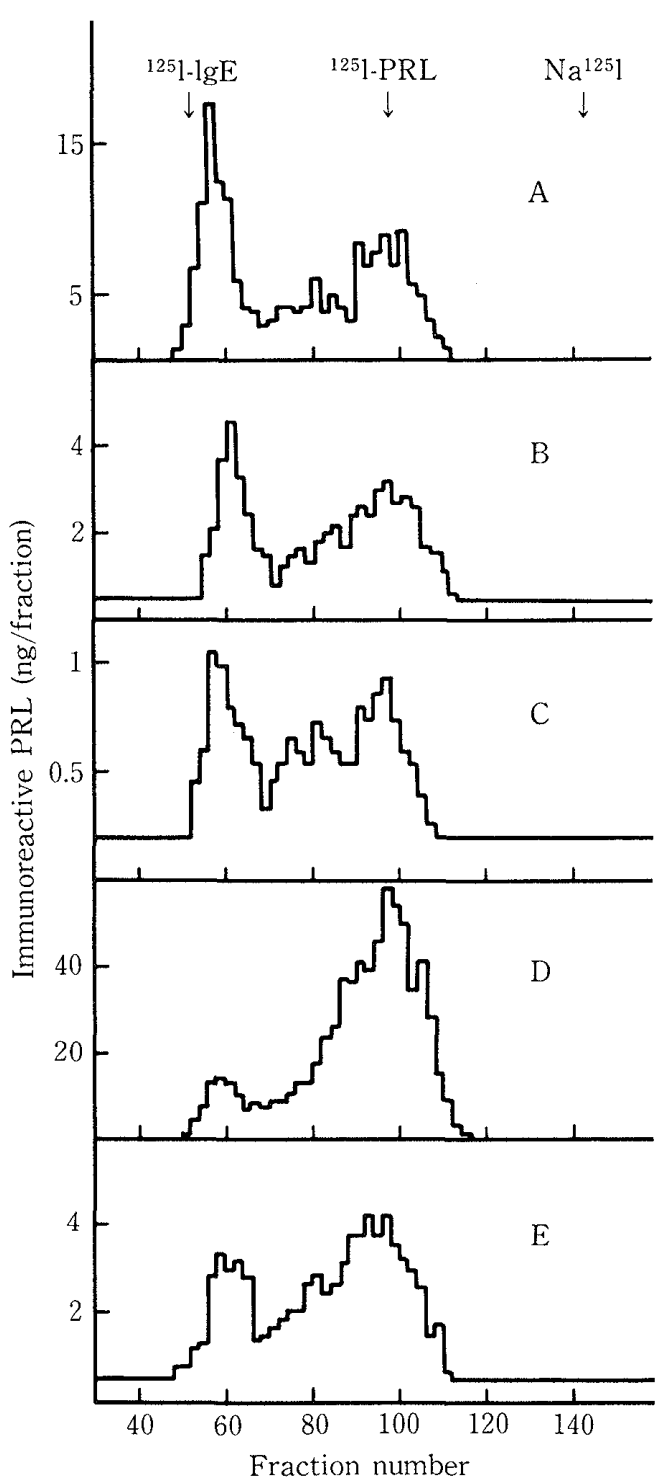

Fig. 2.

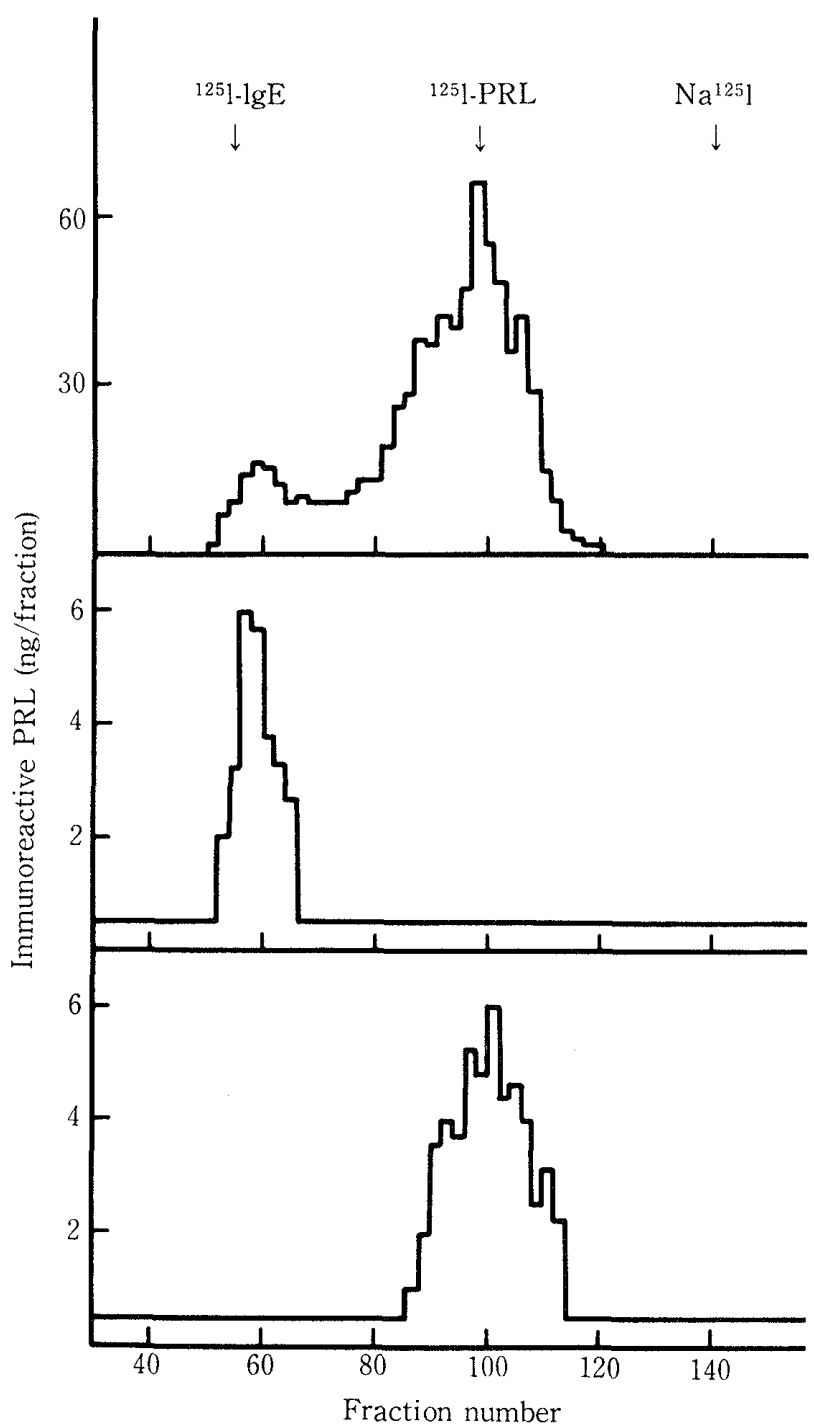

Fig. 3.

Fig. 2. Gel filtration patterns of IR-PRL in serum obtained from 5 pituitary adenoma on a Sephadex G-100 column $(2.6 \times 50 \mathrm{~cm})$ eluted with $0.1 \mathrm{M}$ ammonium acetate buffer. A, B, D and E; PRL-secreting tumors., C; GH-secreting tumors. The substances used for markers are shown at the top.

Fig. 3. Gel filtration pattern of IR-PRL in serum obtained from a patient with PRL-secreting tumor (upper panel; Fig. 2 D). Rechromatographic pattern of fraction corresponding to peak 1 (middle panel), Rechromatographic pattern of fraction corresponding to monomeric PRL (lower panel). The substances used for markers are shown at the top.

that there is no difference in the elution pattern between the patients with pituitary adenoma and normal controls, and the proportion of peak 2 is greater than that of peak 1. The reason for this discrepancy between our results and others on the gel filtration patterns may be due to the difference of elution buffer used. Namely, in many other investigations concerning PRL heterogeneity, phosphate buffer, $\mathrm{pH} 7.4$ has been used as elution buffer on gel filtration (Shu \& Frantz, 1974; Kiefer \& Malarkey, 1974; Benveniste 


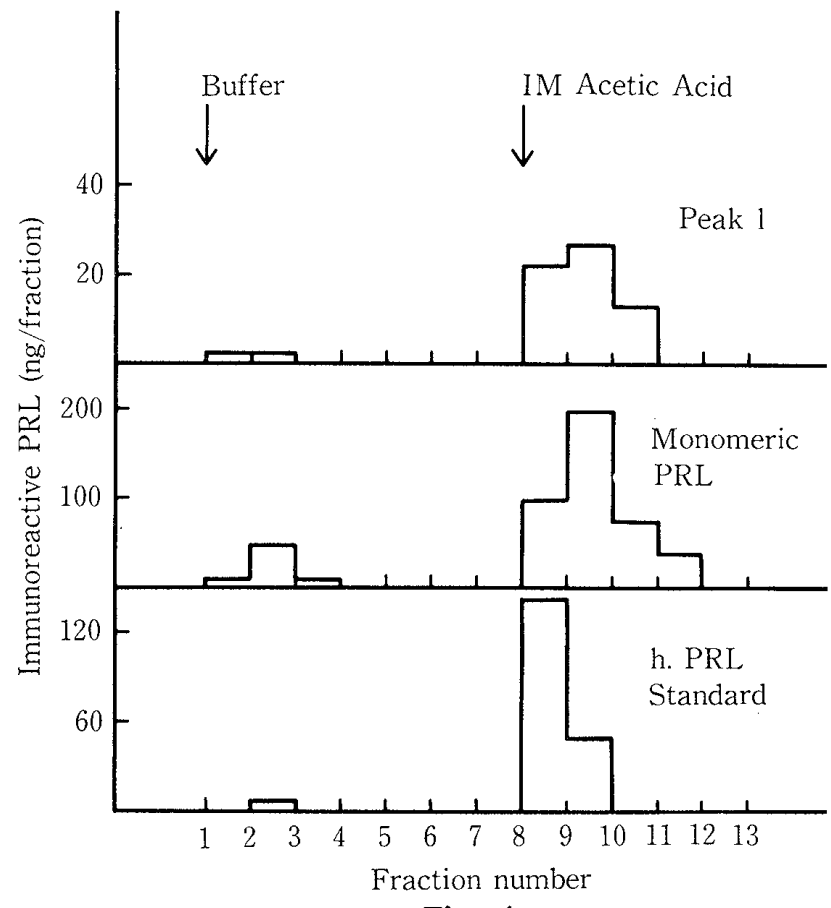

Fig. 4.

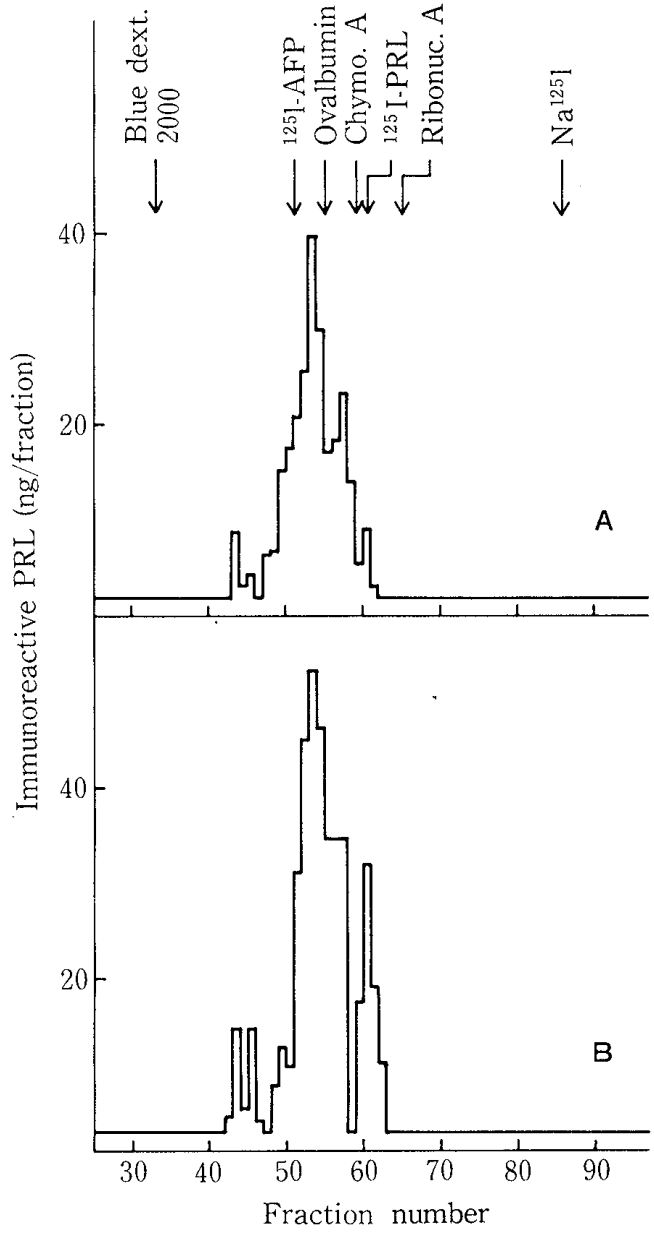

Fig. 5.

Fig. 4. Elution patterns of the peak 1, monomeric PRL and human PRL standard on affinity chromatography with anti-PRL Sepharose. After application of $1.0 \mathrm{ml}$ of sample, the column was washed by $8 \mathrm{ml}$ of buffer, and then bound materials were eluted with $1 \mathrm{M}$ acetic acid.

Fig. 5. Rechromatographic patterns of the peak 1 from pregnant woman (A) and patient with PRL-secreting tumor (B) on Sepharose CL-6B column $(1.0 \times 50 \mathrm{~cm})$ eluted with $0.1 \mathrm{M}$ ammonium acetate buffer, containing $6 \mathrm{M}$ guanidine- $\mathrm{HCl}$ and $0.02 \mathrm{M}$ dithiothreitol. The substances used for markers are shown at the top.

et al., 1979).

In contrast, we have used ammonium acetate buffer, $\mathrm{pH} 4.8$, because PRL readily undergo the effect of proteinase inhibitor and adsorb to glassware in phosphate buffer. Also, phosphate buffer has been proven to be entirely inadequate for the lyophilization which is necessary to detect IR-PRL in each fraction after gel filtration of serum with low concentration of PRL.

Recently, it has been reported that the hormone precursor and fragment are increased in plasma and tissues of various hormone producing tumors as compared to normal subjects (Yamaguchi et al., 1981; Yanaihara, 1980).

In conclusion, the presence of our macromolecular PRL appears to be an intrinsic 


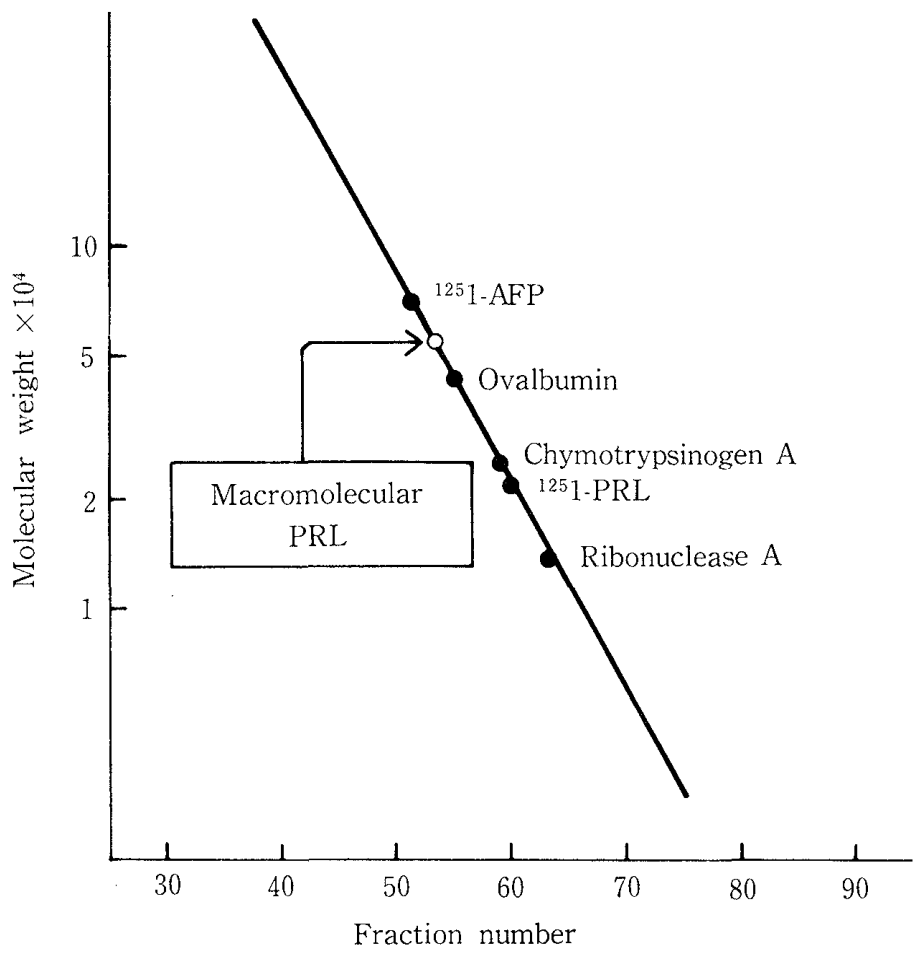

Fig. 6. Estimation of the molecular weight of the peak 1 based on the results described in Fig. 5. The log molecular weight of the calibration standards are plotted against fraction number.

feature of PRL especially observed in serum of patients with pituitary tumor or pregnant women rather than the artifact under experimental procedures, though its physiological significance, the mechanism of appearance in circulation and the probability of the precursor of native forms of PRL remain to be elucidated.

\section{Aknowledgments}

We would like to thank the National Pituitary Agency, NIAMDD, for providing us with human PRL antiserum.

\section{Reference}

Benveniste, R., Helman, J. D., Orth, D. N. et al. (1979): Circulating big human PRL: Conversion to small human PRL by reduction of disulfide bonds. J. Clin. Endocrinol. Metab., 48: 883-886.

Garnier, P. E., Aubert, M. L., Kaplan, S. L. et al. (1978): Heterogeneity of pituitary and plasma prolactin in man. J. Clin. Endocrinol. Metab., 47: 1273-1281.

Kataoka, K. (1981): Studies on the heterogeneity of human prolactin. Folia Endocrinol. Jap., 57: 16221631.

Kiefer, K. A. \& Malarkey W. B. (1978): Size heterogeneity of hPRL in CSF and serum: Experimental conditions that alter gel filtration patterns. J. Clin. Endocrinol. Metab., 46: 119-124. 
Rogol, A. D. \& Rosen, S. W. (1974): PRL of apparent large molecular size: The major immunoreactive PRL component in plasma of a patient with a pituitary tumor. J. Clin. Endocrinol. Metab., 38: $714-717$.

Shoupe, D., Montz, F. J., Kletzky,, O. A. et al. (1983): Prolactin molecular heterogeneity. Am. J. Obstet. Gynecol., 147: 482-487.

Suh, H. K. \& Frantz A. G. (1974): Size heterogeneity of hPRL in plasma and pituitary extracts. J. Clin. Endocrinol. Metab., 39: 928-935.

Whittaker, P. G., Wilcox, T. \& Lind, T. (1981): Maintained fertility in a patient with hyperprolactinemia due to big big PRL. J. Clin. Endocrinol. Metab., 53: 863-866.

Yamag:ıchi, K., Abe, K., Ohmani, S. et al. (1981): The presence of macromolecular vasoactive intestinal polypeptide in VIP-producing tumors. Gastroenterology., 79: 687-694.

Yanaihara, N. (1980): Hormon precursor. Clin. Endocrinol., 9: 223-234.

\section{妊婦および下垂体腺腫患者血清中の Macromolecular Prolactin の存在}

大浪 俊平 ${ }^{1}$. 江藤 澄哉 ${ }^{2}$

1産業医科大学病院放射線部 22産業医科大学第1内科学教室

要 白：妊婦および下垂体腺腫患者血清の PRL の heterogeneity，とくに macromolecular PRL の存在について検討した. 妊婦血清のゲル滤過では, immunoreactive PRLの主な peak は monomeric PRLの溶出部位に認められ, さらに小さな peakを void volume 附近 (peak 1) および void volume と monomeric PRLの間 (peak 2) に認めた. 妊婦ではこの peak 1, peak 2 の占める割合は，それぞれ全免疫活性の 8-12\%，4-9\%であった。 こ れに対し下垂体腺腫患者では peak 1, peak 2 の占める割合は $18-40 \%$, 5-17\% で peak 1 の著明な増加を認めた。 上記 peak 1 を $6 \mathrm{M}$ 塩酸グアニジン, $0.02 \mathrm{M}$ dithiothreitolの 蛋白変性条件下で再溶出させると妊婦, 下垂体腺腫患者とも $\alpha$-fetoprotein と oval bumine の間に peak が出現し，その推定分子量は約 54,000であった. 以上のことから， この peak 1 は monomeric PRLの noncovalent aggregationまたは disulfide bridgeによ る産物ではなく macromolecular PRL である可能性が示唆された。

J. UOEH (産業医大誌)，7(2)：185-192

(1985) 